\title{
The Education on the Utilization of the MCH Handbook Using the Brainstorming Method on the Fulfillment of Nutritional Intake and Developmental Stimulation of Children Under Two Years (aged 6-24 Months) in Gunung Kapur, Lempake Village
}

\author{
Umi Kalsum ${ }^{1}$, Lukman Nulhakmin ${ }^{1}$, Sukri Palutturi ${ }^{2}$ \\ ${ }^{1}$ Health Polytechnic of the Ministry of Health, East Kalimantan, Samarinda, \\ ${ }^{2}$ Faculty of Public Health, Hasanuddin University, Makassar
}

\begin{abstract}
Introduction: Optimal growth and development in children under two years is usually supported by good nutritional status. In addition, there is also a need for developmental stimulation from the mother, family and closest people to support children's intelligence. The government has long launched the Maternal and Child Health $(\mathrm{MCH})$ Handbook as an attempt to assist mothers in meeting the needs of their children. However, the implementation of the program is still not optimal. This can be proven by the number of nutritional status and development of children which does not match their age that is still quite high.
\end{abstract}

Method: This study was a quasi-experimental study, with a pre-test and post-test nonequivalent control group design. The number of samples used was 60 children under two years, which was taken from a population of 131 children under two years in Gunung Kapur. The sampling technique used was non-probability sampling with consecutive sampling method. The instrument used was a questionnaire adapted from the $\mathrm{MCH}$ Handbook. Data were then analyzed using univariate and bivariate analyses with independent $\mathrm{t}$-test.

Results: The results of hypothesis testing with Paired T-Test showed that there was an effect of education on the utilization of the MCH Handbook using the brainstorming method on the fulfillment of nutritional intake $(\mathrm{p}$ value $=0.001)$ and developmental stimulation $(\mathrm{p}$ value $=0.001)$. Analysis of the difference on the two groups showed that the treatment group with the educational intervention using the MCH Handbook using the brainstorming method had a greater effect on the fulfillment of nutritional intake and developmental stimulation with the Independent T-Test $(p$ value $=0.001)$ compared to the control group.

Conclusion: There is an effect of education on the utilization of the MCH Handbook using the brainstorming method on the fulfillment of nutritional intake and developmental stimulation of children under two years (aged 6-24 months) in Gunung Kapur, Lempake Village.

Keywords: Education, nutritional intake, developmental stimulation.

\section{Introduction}

Children are important human resources as the successor of a future nation. As adults, children who have

\section{Corresponding Author:}

Sukri Palutturi

Faculty of Public Health, Hasanuddin University, Makassar e-mail: sukritanatoa72@gmail.com healthy and optimal growth and development are able to develop the nation properly and wisely. The quality of the nation in the future is determined by the quality of today's children. It is supported by Sofyan Djalil as Head of the National Development Planning Board (Bappenas) together with UNICEF stating that $30 \%$ of the total population of Indonesia is children. They are $100 \%$ of the future of the nation and deserve attention in terms of growth and development from various circles ${ }^{1}$. 
Unfortunately, growth and developmental delay in children is still a serious problem in both developed and developing countries in the world ${ }^{2-5}$. This is also an urban health problems ${ }^{1}$. Based on Indonesia's health profile in 2011, 13-18\% of children experienced developmental delay $^{6}$.

Furthermore, the Profile of Indonesian Children in 2015 shows that $16.17 \%$ or $13,396,485$ of Indonesia's population are children under two years. The prevalence of children under two years with malnutrition shows that $17.9 \%$ and $4.9 \%$ suffer from malnutrition. Besides, in East Kalimantan Province, there were 19.4\% children under two years with malnutrition in 2010. This condition has almost reached the national standard of $20 \%$, which so far still needs to get much concern? ${ }^{7}$.

In fact, mother is primary care or who has direct involvement in process of providing care and feeding for children under two years ${ }^{8-10}$. Thus, mothers have a very important role in meeting children's needs. Those who have children under two years should know or have read the contents of the Maternal and Child Health (MCH) Handbook. This book contains information about instructions, guidelines and ways to achieve maternal and child health as a government effort to increase knowledge and behavior in healthy living. A correct and consistent perception or view of the $\mathrm{MCH}$ Handbook as a tool to monitor children's health and growth and development is needed ${ }^{11}$. Perceptions of an object, whether right or wrong, good or bad, positive or negative, cause a response to a person, so that it can be the basis for determining positive or negative attitudes.

Considering the aforementioned phenomenon, researchers are interested in conducting a study entitled "The Effect of the Educationon the Utilization of the MCH Handbook Using the Brainstorming Method on the Fulfillment of Nutritional Intake and Developmental Stimulation of Children Under Two Years (aged 6-24 Months) in Gunung Kapur, Lempake Village".

\section{Materials and Method}

Research Location: The research was carried out in 5 Integrated Services Post (Posyandu) spread out in Gunung Kapur, Lempake Village.

Research Design: This study was a quasiexperimental study, with a pre-test and post-test nonequivalent control group design.
Population and Sample: The population in this study was 131 mothers who have children under two years (aged 6-24 months) in Gunung Kapur, Lempake Village. By using consecutive sampling, 60 samples were obtained which were divided into treatment and control groups.

Data Collection Method: The data were collected by conducting a pre-test using a questionnaire for the fulfillment of nutritional intake and developmental stimulation in the treatment and control groups. It was then continued by providing education regarding the utilization of the MCH Handbook with the brainstorming method in the treatment group. After one month, a post test was carried out using a questionnaire on the fulfillment of nutritional intake and developmental stimulation in the treatment and control groups as evaluation materials.

Data Analysis: The data that had been collected were analyzed, including univariate and bivariate analyses, using independent t-test to determine the effect of education on the utilization of the MCH Handbook with the brainstorming method on the fulfillment of nutritional intake and developmental stimulation of children under two years (aged 6-24 months) in Gunung Kapur, Lempake Village.

\section{Results}

\section{Univariate Analysis:}

\section{Respondent Characteristics:}

Table 1: Characteristics of Mothers Who Have Children Under Two Years (Age 6-24 Months) in Control and Treatment Groups in Gunung Kapur, Lempake Village

\begin{tabular}{|l|c|c|}
\hline \multirow{2}{*}{ Variables } & \multicolumn{2}{|c|}{ Total N $=\mathbf{6 0}$} \\
\cline { 2 - 3 } & $\mathbf{n}$ & $\mathbf{\%}$ \\
\hline Age & & \\
$<20$ years & 1 & 1.7 \\
$20-29$ years & 32 & 53.3 \\
$30-40$ years & 19 & 31.7 \\
$>40$ years & 8 & 13.3 \\
\hline Last Education & & \\
Elementary School/equivalent graduate & 9 & 15.0 \\
Junior High School/equivalent graduate & 14 & 23.3 \\
Senior High School/equivalent graduate & 32 & 53.3 \\
College graduate & 5 & 8.3 \\
\hline
\end{tabular}




\begin{tabular}{|l|c|c|}
\hline \multirow{2}{*}{ Variables } & \multicolumn{2}{|c|}{ Total N=60 } \\
\cline { 2 - 3 } & $\mathbf{n}$ & $\mathbf{\%}$ \\
\hline Occupation & 52 & \\
Housewife & 1 & 1.7 \\
Civil Servant/Army/Police & 7 & 11.7 \\
Entrepreneur & & \\
\hline Income (Rupiah) & 29 & 48.3 \\
$<2,000,000$ & 30 & 50.0 \\
$2,000,000-4,000,000$ & 1 & 1.7 \\
$>4,000,000$ & & \\
\hline
\end{tabular}

Based on Table 1, it can be seen that the characteristics of mothers based on age indicate that most of them are in the 20-29 years category as much as $53.3 \%$. The characteristics of mothers based on the last education indicate that most of them are junior high school/ equivalent graduates as much as $53.3 \%$. Moreover, the characteristics of mothers based on occupation indicate that almost all of them are housewives as much as $86.7 \%$. In addition, the characteristics of mothers based on family income show that some are in the $2,000,000$ $4,000,000$ category as much as $50.0 \%$.

Fulfillment of Nutritional Intake before and after Education Given to Control and Treatment groups:

Table 2: Fulfillment of Nutritional Intake Before and After Education Given to Control and Treatment Groups

\begin{tabular}{|l|c|c|c|}
\hline Variables & N & Mean & SD \\
\hline Fulfillment of Nutritional Intake Treatment & & & \\
Before & 30 & 48.91 & 23.932 \\
After & 30 & 83.30 & 11.490 \\
\hline Control & & & \\
Before & 30 & 43.44 & 23.363 \\
After & 30 & 44.97 & 24.169 \\
\hline
\end{tabular}

Based on Table 2, the mean of fulfillment of nutritional intake variable for the treatment group before the education was 48.91 and after the education was
83.30. It indicates that there was a significant increase with the difference of the mean before and after the education (34.39).

\section{Developmental Stimulation Before and After Education Given to Control and Treatment groups}

Table 3: Statistical Description of Developmental Stimulation Before and After Education Given to Control and Treatment Groups

\begin{tabular}{|l|c|c|c|}
\hline Variables & n & Mean & SD \\
\hline Developmental Stimulation Treatment & & & \\
Before & 30 & 58.03 & 22.021 \\
After & 30 & 83.30 & 11.490 \\
\hline Control & & & \\
Before & 30 & 59.30 & 18.107 \\
After & 30 & 60.00 & 17.794 \\
\hline
\end{tabular}

Based on Table 3, the mean of developmental stimulation variable for the treatment group before the education was 58.03 and after the education was 83.30.
It indicates that there was a significant increase with the difference of the mean before and after the education (25.27). 
Bivariate Analysis:

Paired T-Test:

Table 4: The Results of Bivariate Analysis of Fulfillment of Nutritional Intake and Developmental Stimulation in Treatment and Control Groups Using Paired T-Test

\begin{tabular}{|c|c|c|c|}
\hline Variables & $\mathbf{N}$ & Mean \pm SD & p value \\
\hline $\begin{array}{l}\text { Fulfillment of Nutritional Intake Treatment } \\
\text { Before } \\
\text { After }\end{array}$ & $\begin{array}{l}30 \\
30\end{array}$ & $\begin{array}{l}48.91 \pm 23.932 \\
83.30 \pm 11.490\end{array}$ & 0.001 \\
\hline $\begin{array}{l}\text { Control } \\
\text { Before } \\
\text { After }\end{array}$ & $\begin{array}{l}30 \\
30\end{array}$ & $\begin{array}{l}43.44 \pm 23.363 \\
44.97 \pm 24.169\end{array}$ & 0.055 \\
\hline $\begin{array}{l}\text { Developmental Stimulation } \\
\text { Treatment } \\
\text { Before } \\
\text { After }\end{array}$ & $\begin{array}{l}30 \\
30\end{array}$ & $\begin{array}{l}58.03 \pm 22.021 \\
83.30 \pm 11.490\end{array}$ & 0.001 \\
\hline $\begin{array}{l}\text { Control } \\
\text { Before } \\
\text { After }\end{array}$ & $\begin{array}{l}30 \\
30\end{array}$ & $\begin{array}{l}59.30 \pm 18.107 \\
60.00 \pm 17.794\end{array}$ & 0.079 \\
\hline
\end{tabular}

Based on Table 4, it was found that $\mathrm{p}=0.001$ $<0.05$ for fulfillment of nutritional intake variable and developmental stimulation variable in the treatment group. Thus, there was an effect of education on fulfillment of nutritional intake and developmental stimulation in the treatment group in Gunung Kapur, Lempake Village.

Independent T-Test:

Table 5: The Results of Bivariate Analysis of Fulfillment of Nutritional Intake and Developmental Stimulation in Treatment and Control Groups Using Independent T-Test

\begin{tabular}{|c|c|c|c|}
\hline Variables & $\mathrm{N}$ & Mean \pm SD & $\mathrm{p}$ value \\
\hline $\begin{array}{l}\text { Fulfillment of Nutritional Intake Before } \\
\text { Treatment } \\
\text { Control }\end{array}$ & $\begin{array}{l}30 \\
30\end{array}$ & $\begin{array}{c}48.91 \pm 23.932 \\
43.44 \pm 24.169\end{array}$ & 0.374 \\
\hline $\begin{array}{l}\text { After } \\
\text { Treatment } \\
\text { Control }\end{array}$ & $\begin{array}{l}30 \\
30 \\
\end{array}$ & $\begin{array}{l}83.30 \pm 11.490 \\
44.97 \pm 24.169\end{array}$ & 0.001 \\
\hline $\begin{array}{l}\text { Developmental Stimulation } \\
\text { Before } \\
\text { Treatment } \\
\text { Control }\end{array}$ & $\begin{array}{l}30 \\
30\end{array}$ & $\begin{array}{l}58.03 \pm 22.021 \\
59.30 \pm 18.107\end{array}$ & 0.809 \\
\hline $\begin{array}{l}\text { After } \\
\text { Treatment } \\
\text { Control }\end{array}$ & $\begin{array}{l}30 \\
30\end{array}$ & $\begin{array}{l}83.30 \pm 11.490 \\
60.00 \pm 17.794\end{array}$ & 0.001 \\
\hline
\end{tabular}

Based on Table 5, the mean and standard deviation values of the fulfillment of nutritional intake variable before treatment were $48.91 \pm 23.932$, while the values of the control group were $43.44 \pm 24.169$ with $p=0.374$ $>0.05$. It means that there was no significant difference in the difference value between the two groups. 
Additionally, the mean and standard deviation values of the fulfillment of nutritional intake variable after the treatment were $83.30 \pm 11.490$, while the values of the control group were $44.97 \pm 24.169$ with $p=0.001<$ 0.05 . It means that there was significant difference in the difference value between the two groups.

More importantly, the mean and standard deviation values of the treatment group before the treatment were $58.03 \pm 22.021$, the values of the control group were $59.30 \pm 18.107$ with $p=0.809>0.05$. It means that there was no significant difference in the difference value between the two groups. Besides, the mean and standard deviation values of the treatment group after treatment were $83.30 \pm 11.490$, while the values of the control group were $60.00 \pm 17.794$ with $p=0.001<$ 0.05 . It means that there was significant difference in the difference value between the two groups.

Therefore, it can be said that there was no significant difference between the fulfillment of nutritional intake in treatment and control groups before using the $\mathrm{MCH}$ Handbook. However, there was a significant difference between the fulfillment of nutritional intake in the treatment and control groups after the treatment in the form of education on the utilization of the $\mathrm{MCH}$ Handbook.

\section{Discussion}

a. The Effect of the Education on the Utilization of the MCH Handbook Using the Brainstorming Method on the Fulfillment of Nutritional Intake of Children Under Two Years (aged 6-24 Months) in Gunung Kapur, Lempake Village

In this research, the mean of the fulfillment of nutritional intake variable in the treatment group before the education on the utilization of the MCH Handbook was 48.91. Mothers, as research respondents, then received the education on the utilization of $\mathrm{MCH}$ Handbook with the brainstorming method.

Besides, the mean of the fulfillment of nutritional intake variable in the treatment group after the education on the utilization of the MCH Handbook was 83.30. This shows an increase in the mean of fulfillment of nutritional intake variable before and after the education on the utilization of the $\mathrm{MCH}$ Handbook, which is 34.39 with $\mathrm{p}=0.001<0.05$.
Moreover, mothers in the treatment and control groups affirmed that they had read the MCH Handbook. However, they only read without applying how to fulfill proper nutritional intake for children under two years (aged 6-24 months). In fact, knowledge is closely related to the amount of information a person has. The more information a person has, the higher their knowledge ${ }^{12}$. Brainstorming method was deliberately chosen with the aim of increasing the active role of the mother, generating creative roles, stimulating participation, and creating a pleasant atmosphere ${ }^{13}$.

\section{b. The Effect of the Education on the Utilization of the MCH Handbook Using the Brainstorming Method on the Developmental Stimulation of Children Under Two Years (aged 6-24 Months) in Gunung Kapur, Lempake Village}

In this research, the mean of the developmental stimulation variable in the treatment group before the education on the utilization of the MCH Handbook was 58.03 .

More importantly, the mean of developmental stimulation after education on the utilization of the $\mathrm{MCH}$ Handbook was 83.30. It indicates an increase in the mean of developmental stimulation before and after the education on the utilization of the MCH Handbook, which was 25.27 with p $0.001<0.05$.

Here, the mothers admitted that they had read the MCH Handbook, but they did not know the developmental stimulation that should be given to children based on age.

In this study, it was found that there was an increase in the mean value in the treatment group after the education. These results are in line with the research conducted by ${ }^{14}$ Muflihah (2017) which claimed that mother's knowledge and skills in providing developmental stimulation to toddlers have increased after receiving education.

\section{c. The Differences in the Fulfillment of Nutritional Intake and Developmental Stimulation in the Control and Treatment Groups}

The results of the research analysis obtained independent t-test on the fulfillment of nutritional intake and developmental stimulation in the control and treatment groups, that is $\mathrm{p}=0.001<0.05$. 
Education with the brainstorming method has a significant effect on the results obtained. It is in accordance with the research conducted by ${ }^{15}$ (Syafi'udin, Wantiyah dan Kushariyadi, 2018)which proved that health education using the brainstorming method is more effective than the lecture method. One of the advantages of the brainstorming method is that it is able to provide stimulation for all participants to actively take part in it, besides that it uses a little equipment.

\section{Conclusion and Recommendations}

There is an effect of education on the utilization of the MCH Handbook using the brainstorming method on the fulfillment of nutritional intake and developmental stimulation in Gunung Kapur, Lempake Village. Last but not least, this research recommends the Health Office to further motivate community health center officers in socializing and educating mothers with toddlers regarding the utilization of the $\mathrm{MCH}$ Handbook. The community health center is expected to be able to hold regular meetings with Integrated Services Post cadres in providing education on the utilization of the $\mathrm{MCH}$ Handbook to mothers.

Ethical Clearance: Health Polytechnic of the Ministry of Health, East Kalimantan, Samarinda.

Source of Funding: Health Polytechnic of the Ministry of Health, East Kalimantan, Samarinda

\section{Conflict of Interest: Nil}

\section{References}

1. Olsson G. Laporan Tahunan Indonesia 2015. Jakarta: UNICEF; 2015.

2. Kamba I, Razak A, Saifuddin S, Palutturi S. The Effect of Video on the Change of Attitude Toward Stunting Prevention among Children in State Senior High School 1 Topoyo, Central Mamuju. Indian Journal of Public Health Research \& Development. 2019;10(8):1315-1320.

3. Palutturi S, Syam A, Asnawi A. Stunting in a political context: A systematic review. Enfermería Clínica. 2020;30:95-98.

4. Kamba I, Razak A, Saefuddin S, Palutturi S. Video Effect for the Prevention of Knowledge Increasing Stunting in State High School 1 Children in Topoyo Central Mamuju. Indian Journal of Public Health Research \& Development. 2019;10(10):14221427.
5. Syam A, Palutturi S, Djafar N, Astuti N, Thaha AR. Micronutrients and growth of children; a literature review. International Journal of Medical Science and Public Health. 2016;5(10):1981-1987.

6. Depkes R. Laporan Nasional Riset Kesehatan Dasar (Riskesdas) Tahun 2010. Badan Penelitian dan Pengembangan Kesehatan. 2010.

7. Kemenkes RI. Profil Anak Indonesia 2015 Jakarta: Kemenkes-Kementeria Pemberdayaan Perempuan \& Perlindungan Anak-BPS 2015.

8. Amiruddin R, Palutturi S, Rahman S. Training effect to the knowledge and skills of midwives in maternity health services at primary health care. International Journal Of Community Medicine And Public Health. 2018;5(11):4651-4655.

9. Tahir M, Amiruddin R, Palutturi S, Rivai F, Saleh LM. Religius Character in Improving Primary Health Services Quality in South Sulawesi. Indian Journal of Public Health Research \& Development. 2019;10(10):1428-1432.

10. Amiruddin R, Palutturi S, Rahman SA. Increasing Midwifery Skill for Pregnancy Health Care with Ammuntuli Bija Tianang Na Beja-Beja Model. Indian Journal of Public Health Research \& Development. 2018;9(9).

11. Sistiarani C, Gamelia E, Sari DUP. Fungsi pemanfaatan buku KIA terhadap pengetahuan kesehatan ibu dan anak pada ibu. Kesmas: National Public Health Journal. 2014;8(8):353-358.

12. Mardisar D, Sari RN. Pengaruh akuntabilitas dan pengetahuan terhadap kualitas hasil kerja auditor. Simposium nasional akuntansi X. 2007:26-28.

13. Winancy W, Raksanagara AS, Fuadah Y. Perbandingan penerapan metode Brainstorming dan buzz Group terhadap peningkatan pengetahuan suami ibu hamil tentang tanda bahaya kehamilan, persalinan, dan nifas (studi Kasus di Bogor). SEAJOM: The Southeast Asia Journal of Midwifery. 2015;1(1):1-9.

14. Muflihah IS. PENGARUH PELATIHAN STIMULASI DETEKSI DAN INTERVENSI DINI TUMBUH KEMBANG ANAK. Bidan Prada: Jurnal Publikasi Kebidanan Akbid YLPP Purwokerto. 2017.

15. Syafiudin M, Wantiyah W, Kushariyadi K. Pengaruh Pendidikan Kesehatan Metode Brainstorming dan Video terhadap Pengetahuan tentang Demam 
Berdarah pada Keluarga di Wilayah Kerja Puskesmas Puger Kabupaten Jember (The effect of Health Education Brainstorming Method and Video to the Knowledge about. Pustaka Kesehatan. 2018;6(1):141-146.
16. Pandora J, Kartasurya MI, Winarni S. Penggunaan Buku KIA Sebagai Media Edukasi pada Ibu Hamil (Studi di Wilayah Kerja Puskesmas Tlogosari Kulon, Tahun 2018). Jurnal Kesehatan Masyarakat (e-Journal). 2018;6(2):63-73. 